\title{
The Effect of Ability, Motivation, Discipline, and Job Satisfaction on Employee Performance an Empirical Study on PT. Sung Chang Indonesia
}

\author{
Kartinah \\ Faculty of Economics and \\ Business \\ Universitas Janabadra \\ Yogyakarta, Indonesia \\ kartinah@janabadra.ac.id
}

\author{
Nurwiyanta \\ Faculty of Economics and \\ Business \\ Universitas Janabadra \\ Yogyakarta, Indonesia \\ nurwiyanta@Janabadra.ac.id
}

\author{
Ridwan \\ Faculty of Economics and \\ Business \\ Universitas Janabadra \\ Yogyakarta, Indonesia \\ ridwan@janabadra.ac.id
}

\author{
Titi Laras \\ Faculty of Economics and \\ Business \\ Universitas Janabadra \\ Yogyakarta, Indonesia \\ titilaras@janabadra.ac.id
}

\begin{abstract}
This study aims to examine the effect of ability, motivation, discipline, and job satisfaction on employee performance. The population in this study were all employees of PT. Sung Chang Indonesia branch of Kulon Progo, totaling 1502 people. The sampling technique used stratified random sampling with the formula from Isaac and Michael, obtained 229 samples. Data collection using a closed questionnaire. The research model provides a determination coefficient of 50 percent and has met the goodness of fit requirements. Hypothesis testing uses the $t$ statistical test. Estimation using multiple linear regression, with the help of the SPSS.20 program, this study succeeded in providing statistical support that ability, motivation, work discipline, and job satisfaction have a significant positive effect on employee performance.
\end{abstract}

Keywords: Ability, motivation, discipline, job satisfaction, employee performance

\section{INTRODUCTION}

It should be realized that in this 4.0 era, not all activities can be replaced by machines. There are still many large companies that still rely on their operations to be carried out by humans. Like PT Sung Chang Indonesia (PT SCI) which was founded in 1986 in Seoul, Korea. As the largest wig and hair extension company in the world, it is possible, thanks to the hard work and sincerity of its tens of thousands of employees. In Indonesia, PT Sung Chang, which is a labor-intensive PMA, has 7 factories in Central Java and DIY. Company which emphasizes the importance of human resources (HR) who have valuable, rare, inimitable and nonsubstitutable characteristics [1]. This is in line with the resource-based concept [2] which states that the uniqueness and integration of HR managerial practices is the key to the concept of sustainable competitive advantage.

This advantage arises when a company manages to do something that other companies cannot. The company is able to bring every employee to achieve the predetermined performance. Performance is the level of success in carrying out tasks and the ability to achieve goals that have been detected by knowledge. Performance can be defined as work that can be achieved by a person or group of people in an organization, in accordance with their respective authorities and responsibilities, to achieve the goals of the organization concerned legally, not to violate the law, and in accordance with morals and ethics. The company wants every employee to perform optimally, to be able to meet the European, American and Japanese markets.

Many factors can affect employee performance. These factors can arise from individual employees, internal companies and external companies. Flippo (1998) states that employee performance is influenced by ability, motivation, job satisfaction, leadership, work climate, organizational culture, and work discipline. However, this study only raises four factors that affect employee performance, namely ability, motivation, discipline, and employee job satisfaction.

Ability is an individual's capacity to carry out various tasks in a particular job [3]. All abilities of a person are essentially composed of two sets of factors, namely intellectual abilities, often called soft skills and physical abilities (hard skills). Abilities, namely abilities that are formed from a number of competencies possessed by an employee including loyalty, discipline, cooperation and responsibility. Competence can also reduce the error rate in each division (production, marketing, finance and human resources) so that it can improve performance [4].

Motivation is very important in every company. Employees who have high work motivation can encourage employees to work more enthusiastically, do not give up easily, work creatively, and can make a positive contribution to their work and responsibilities. Apart from motivation, discipline is also important for company performance. Discipline in a company can be seen from how employees carry out their responsibilities in accordance with predetermined rules. High employee discipline will create a more conducive work atmosphere and have a positive impact on company activities. Disciplined employees will also work effectively and efficiently so as to avoid wasting time and energy. For this reason, a company that has high discipline will certainly find it easier to achieve its goals because the system or rules that apply can be carried out properly by employees. 
Job satisfaction reflects a person's feelings about his job. This can be seen in the positive attitude of employees towards work and everything they face in their work environment. Each employee will have a different level of satisfaction according to the value system that applies to him. The more aspects of the job that are in accordance with the wishes of the employee, the higher the level of satisfaction he feels, and vice versa. This has been shown by [5] and [6] whose research shows that motivation and job satisfaction have a positive effect on employee performance. From this background, this study raises the title "The Influence of Ability, Motivation, Discipline, and Job Satisfaction on Employee Performance. Studies at PT. Sung Chang Indonesia "

.Theory Study and Hypothesis Development

\section{A. Effect of Ability on Employee Performace}

Performance is the work that can be achieved by a person or group of people in an organization, in accordance with their respective authorities and responsibilities, in an effort to achieve the goals of the organization concerned legally, does not violate the law and is in accordance with morals and ethics. [7]. [8], suggests that the factors that influence employee performance are: motivation, job satisfaction, leadership, work climate, organizational culture, work discipline, and employee abilities. [9] suggest five indicators of employee performance are: quantity, quality, punctuality, attendance, and the ability to work together. Furthermore, [10] suggested six indicators of employee performance variables, including:

a. Quality. Shows the extent to which the quality of an employee in carrying out his duties includes accuracy, completeness, and neatness.

b. Quantity. The amount generated is realized from a completed activity cycle.

c. Attitude. Attitudes towards the company, other employees and jobs.

d. Cooperation. Employees are able to work with colleagues, employees have a positive attitude towards each team work, and employees are willing to help work team members in completing work.

e. Communication. Employees use each other's information to achieve common goals with both colleagues and direct superiors.

Ability is an individual's capacity to carry out various tasks in a particular job [3]. All abilities of an individual are essentially composed of two sets of factors, namely intellectual abilities, often called soft skills and physical abilities (hard skills). [11] describes "the ability to be a determining factor for the success of the personnel department to maintain effective human resources". Individuals who are unable to solve the problems they face will be considered not serious in doing their work. Michael Zwell in [12] reveals six factors that can influence an employee's abilities, namely: Beliefs and values, skills, experiences, personality characteristics, motivation, and emotional issues.

There have been many studies conducted to show evidence that ability has a positive effect on employee performance. As done by [13], [14], [15], [16], [17], [18], [19], \{20], [21]. All of which show the consistency of support for the concept of experts and empirical evidence that the ability of employees, which Robbin (2008) categorizes into soft skills and hard skills, has a positive effect on employee performance. Employees who have higher abilities will perform higher, and conversely, lower employees' abilities will result in lower performance as well. From the conceptual exposure and empirical evidence,can be formulated the first hypothesis, that ability has a positive influence on employee performance.

\section{B. The Effect of Motivation on Employee Performance}

Motivation is a desire or encouragement in a person to take an action to achieve goals [12]. Desire is a motive that encourages a person to behave in a certain way to achieve his goals. If the behavior is right, then that person will get satisfaction, because the goal is achieved. But if his behavior is not right, then he will not achieve his goal.

There are many well-known motivational theories from various motivational figures, but this research raises the motivation theory of Abraham H. Maslow's hierarchical needs. Maslow identifies human needs and classifies them into five hierarchies of needs, from the most basic needs to the highest needs, as follows:

a) Physiological needs, namely the need for eating, drinking, physical protection, breathing, sex. This need is the most basic level requirement.

b) Safety needs. The need for security, namely the need for protection from threats, dangers, conflicts, and the environment.

c) Love and belonging. The need for love and belonging, namely the need to be accepted by the group, affiliated with, interact, and the need to love and be loved.

d) Esteem needs. The need for self-esteem, namely the need to be respected and appreciated by others.

e) Self-actualization needs. Self-actualization needs, namely the need to show abilities, skills, and self-potential to others. Someone who is at the level of self-actualization needs, will show his best abilities to achieve his / her best / highest career.

There have been many studies conducted to show evidence that motivation has a positive effect on employee performance. As done by [22], [23], [24], [25], [26], [27], [28], [29], and [30]

From the conceptual exposure and empirical evidence, can be formulated a second hypothesis, that motivation has a positive effect on employee performance.

\section{The Effect of Work Discipline on Employee Performance}

Work discipline is an attitude and behavior of a person that shows obedience, obedience, loyalty, unity and order to company or organizational rules and prevailing social norms. Enforcing work discipline is very important for the organization. The existence of work discipline will guarantee the maintenance of order and the smooth execution of work and will produce optimal performance. Work discipline is an attitude of respecting, appreciating, obeying and obeying the applicable regulations, both written and unwritten and being able to carry them out and not to avoid accepting the sanctions, if they violate the duties and authority given to them [13]. Keith Davis in [14] states that "Discipline is management action to enforce organization standards".

Hasibuan (2013), suggests indicators that affect the level of discipline of employees of an organization, namely:

a. Goals and Capabilities. Goals and abilities also affect the level of employee discipline. The goals to be 
achieved must be clear and ideally set as well as challenging enough for employees' abilities.

b. Leadership Model. Leaders must realize that their behavior will be imitated and imitated by their subordinates. Leaders must have high discipline, so that subordinates follow and have high discipline as well.

c. Remuneration. Remuneration also affects employee discipline, because remuneration will give employees satisfaction and love for their work.

d. Justice. Justice is used as the basis for policy in providing remuneration (recognition) or punishment which will stimulate the creation of good employee discipline. With good justice will create good discipline too.

e. Supervision attached. meaning that superiors must be active and directly supervise the behavior, morals, attitudes, work passions, and work performance of their subordinates. Inherent supervision is not just about monitoring work morale and employee discipline, it must also try to find a more effective work system to realize organizational goals. With a good system, internal controls will be created that can reduce errors and support employee discipline and work morale.

f. Legal sanctions. Legal sanctions play an important role in maintaining employee discipline. Legal sanctions must be determined based on logical considerations, make sense and be clearly communicated to all employees.

g. Firmness. Leaders who dare to act decisively apply punishment for employees who are disciplined will be respected and recognized by their leadership by their subordinates. Conversely, if the leadership is not firm, it is difficult for him to maintain discipline in his subordinates, because they think that there are no rules and legal sanctions for disciplinary behavior.

h. Human Relations. Managers must strive to create an atmosphere of harmonious and binding human relations, vertically and horizontally to foster discipline.

There have been many studies conducted to show evidence that work discipline has a positive effect on employee performance. As has been done by [22], [25], [26], [27], [28], [30], [31], [32], [33], [34], [35], [36], [37], [38]. Their research shows the consistency of their support for the concept that work discipline has a positive effect on employee performance.

From the conceptual exposure and empirical evidence,can be formulated the third hypothesis, that work discipline has a positive effect on employee performance.

D. The Effect of Job Satisfaction on Employee Performance

Job satisfaction is one very important factor to get optimal work results. When a person feels satisfaction at work, he will do everything possible to the best of his ability to complete his job assignments. Job satisfaction is a pleasant or unpleasant emotional state in how employees perceive their work [11]. Furthermore, Celluci, Anthony, and David in Mas'ud (2004) suggest four indicators of job satisfaction are: satisfaction with salary, satisfaction with promotion, satisfaction with colleagues, satisfaction with supervisors.

There have been many studies conducted to show evidence that work discipline has a positive effect on employee performance. As was done by [5], [6], [7], [23], [24], [29], [38], [39], [41]. From the conceptual exposure and empirical evidence,can be formulated the fourth hypothesis, that job satisfaction has a positive effect on employee performance.

\section{A. Research Variables}

\section{RESEARCH METHODS}

This study raised four independent variables, namely ability $\left(\mathrm{X}_{1}\right)$, motivation $\left(\mathrm{X}_{2}\right)$, discipline $\left(\mathrm{X}_{3}\right)$, and job satisfaction $\left(\mathrm{X}_{4}\right)$, which were predicted to affect employee performance $(\mathrm{Y})$ as the dependent variable.

\section{B. Population and Sample}

The population of this study were 1502 employees of PT. Sung Chang Indonesia branch of Kulon Progo, which is distributed into thirteen work divisions (cut, sasak, sangchim, curly, post, S / W, cap, knettig, BB / BP, poaching, mechanic, staff, security

guard). Using probability sampling techniques with the method stratified random sampling. The sample size was determined using the formula from Isaac and Michael, and the sample obtained was 229.3

\section{Data Collection Techniques}

This research uses primary data. The data collection technique uses a closed questionnaire, where each alternative answer is weighted on a Likert scale from 1 to 5 .

\section{Analysis Method}

Analysis used multiple linear regression, to the following research econometric models:

\section{RESEARCH RSEULTS AND DISCUSSION}

\section{A. The Hypothesis Testing}

hypothesis of this research was tested using the t statistical test on the econometric model:

$$
Y=\alpha+\beta_{1} X_{1}+\beta_{2} X_{2}+\beta_{3} X_{3}+\beta_{4} X_{4}+
$$

With the help of the SPSS.20 program, the research model has a determination coefficient value of 0.50 and has met the Goodness of Fit requirements. Furthermore, testing the hypothesis using the $t$ statistical test, the following results were obtained: 


\section{B. Discussion}

This study has successfully demonstrated statistical support for Flippo (1998) which states that performance is influenced by ability, motivation, discipline and job satisfaction.

\section{Effect of Ability on Employee Performance}

Results of this study indicate that ability has a significant positive effect on employee performance. This means that the higher the dimensions of ability which include the intellectual abilities and physical abilities of employees, the higher the contribution to improving their performance.

From the resulting multiple linear regression model, the ability to have the largest regression coefficient value of the three other variables, namely motivation, discipline, and job satisfaction is positive at 0.582. This means that each percentage increase in the ability of employees will increase the performance of 0.582. Conversely, each percentage decrease in ability will result in a decrease in performance of 0.582 .

This study supports the research that has been conducted by [13], [14], [15], [16], [17], [18], [19], [20], [21] states that ability has a positive effect on employee performance.

TABLE I. RESULT TABLE T-STATISTICS COEFFICIENTS

\begin{tabular}{|c|c|c|c|c|c|}
\hline \multirow[b]{2}{*}{ Model } & \multicolumn{2}{|c|}{$\begin{array}{l}\text { nstandardized } \\
\text { Coefficients }\end{array}$} & \multirow{2}{*}{$\begin{array}{c}\text { Standardized } \\
\text { Coefficients } \\
\text { Beta }\end{array}$} & \multirow[b]{2}{*}{$\mathrm{t}$} & \multirow[b]{2}{*}{ Sig. } \\
\hline & B & Std. Error & & & \\
\hline 1 (Constant) & .062 & 2.967 & & .021 & .983 \\
\hline Ability & .582 & .070 & .508 & 8.309 & .000 \\
\hline Motivation & .225 & .076 & .192 & 2.952 & .003 \\
\hline Diciplin & .124 & .055 & .115 & 2.267 & .024 \\
\hline $\begin{array}{c}\text { Job } \\
\text { Satisfaction }\end{array}$ & .141 & .059 & .145 & 2.406 & .017 \\
\hline
\end{tabular}

Source: processed data.

From the $\mathrm{t}$ statistical test table, it produces multiple linear regression models:

$$
\gamma=0,062+0,582 X_{1}+0,225 X_{2}+0,124 X_{3}+0,141 X_{4}
$$

\section{Effect of Motivation on Employee Performance} The

Results of this study indicate that motivation has a significant positive effect on employee performance. This means that the higher the motivational dimensions of Maslow's needs, which include the fulfillment of physical needs, safety needs, social needs, achievement needs, and actualization needs, the higher the employee's performance will be.
From the resulting multiple linear regression model, motivation has a positive regression coefficient value of 0.225 . This means that each percentage increase in employee motivation will result in an increase in performance of 0.225 . Conversely, each percentage decrease in employee motivation will result in a decrease in performance of 0.225 .

This study supports the research conducted by [6], [13] [14], [17], [20], [22], [23], [24], [25], [26], [27], [28], [29] [30], that motivation has a positive effect on employee performance.

3. The Effect of Work Discipline on Employee Performance The

Results of this study indicate that discipline has a significant positive effect on employee performance. This means that the higher the disciplinary dimensions which include goals and abilities, exemplary leadership, remuneration, justice, supervision, penalties, assertiveness, and human relations, the higher the employee's performance will be. And vice versa.

From the resulting multiple linear regression model, discipline has a positive regression coefficient value of 0.124 . This means that each percentage increase in employee discipline will result in an increase in performance of 0.124 . Conversely, each percentage reduction in employee discipline will result in a decrease in performance equal to that coefficient.

This study supports the research that has been conducted by [22], [25], [26], [27], [28], [30], [31], [32], [34], [36], [37], [38], that discipline has a positive effect on employee performance.

4.

\section{Performance The}

Effect of Job Satisfaction on Employee

Results of this study indicate that job satisfaction has a significant positive effect on employee performance. This means that the higher the dimensions of job satisfaction which include salary, promotion, coworkers and supervisors, the higher the employee's performance.

From the resulting multiple linear regression model, job satisfaction has a positive regression coefficient of 0.141 . This means that each percentage increase in employee job satisfaction will result in an increase in performance of 0.141 . Conversely, each percentage decrease in employee job satisfaction will result in a decrease in performance of 0.141 .

This study supports the research that has been conducted by [5], [6], [7], [23], [24], [29], [39], [41], with the results that satisfaction has a positive effect on employee performance.

This study shows that the ability has the highest regression coefficient (0.582) compared to the motivation coefficient $(0.225)$, work discipline $(0.124)$, and job satisfaction $(0.141)$ This means that ability is the dominant variable that affects employee performance. This means that management has succeeded in conditioning its employees to have intellectual abilities and skills according to job requirements. On the other hand, the company still has homework to improve the aspects of motivation, work discipline, and employee job satisfaction so that employees can contribute to their performance. 


\section{CONCLUSION}

1. This study succeeds in showing statistical evidence that ability, motivation, discipline, and job satisfaction have a significant positive effect on employee performance.

2. This study also shows that ability has the highest coefficient of influence on improving employee performance, followed by motivation, job satisfaction, and discipline.

3. This study succeeded in providing statistical evidence of support for Flippo (1998) that ability, motivation, discipline, and job satisfaction have a positive effect on employee performance.

\section{REFERENCES}

[1] Wright, P.M., McMahan, G.C., \& McWilliams, A., (1994), "Human resources and sustained competitive advantage: A resource-based perspective, International Journal of Human Resource Management, Vol. 5, pp. 301-326.

[2] Barney, J. (1991), "Firm resources and sustained competitive advantage", Journal of Management, 17: 99-120.

[3] Robbins, Stephen dan Timothy A. Judge. 2008. Perilaku Organisasi. Jakarta: Salemba Empat.

[4] Yang, Y., Lee, P.K.C., Cheng, T.C.E. (2016), Continuous improvement competence, employee creativity, and new service development performance: A frontline employee perspective. International Journal of Production Economics, 171, 275-288.

[5] Juliati, Ati. 2012. Pengaruh Motivasi dan Kepuasan Kerja Terhadap Kinerja Karyawan Bank Muamalat Indonesia Cabang Cirebon. Skripsi. IAIN Syeh Nurjati Cirebon

[6] Isnia, Fariyanti. 2017. Pengaruh Kepuasan Kerja dan Motivasi Kerja Terhadap Kinerja Karyawan PT. PLN (Persero) Distribusi Jawa Tengah dan DIY. Skripsi. Univesitas Katolik Soegijapranata

[7] Bin S.A.S. (2016), The relationship between job satisfaction, job performance and employee engagement: An explorative study. Issues in Business Management and Economics, 4(1), 1-8.

[8] Flippo, Edwin. 1998. Manajemen Personalia Edisi 6. Jakarta : Erlangga

[9] Robert L. Malthis, John Haroln Jackson. 2006. Human Resource Management. Thomson/South-Westen.

[10] Becker, T. E., \& Klimoski, R. J. (1989). A field study of the relationship between the organizational feedback environment and performance. Personnel Psychology, 42(2), 343-358.

[11] Handoko, H. T. (2000). Manajemen Personalia dan Sumberdaya Manusia, Edisi II, Cetakan Keempat Belas. Yogyakarta: BPFE.

[12] Wibowo. 2016. Manajemen Kinerja. Jakarta: Rajawali Pers.

[13] Wijaya, Andree dan Suhaji. 2012. Pengaruh Kemampuan dan Motivasi Terhadap Kinerja Karyawan di ONPM Mandiri Pedesaaan Jawa Tengah. Jurnal. STIE Widya Manggala

[14] Yudha, Bambang Swasto S dan Ika Ruhana. 2013. Pengaruh Motivasi kerja dan Kemampuan Kerja Terhadap Kinerja Karyawan pada PDAM Kota Malang. Jurnal. Universitas Brawijaya

[15] Meidianwar, Margono dan Djumadi. 2014. Pengaruh Kemampuan dan Motivasi Kerja terhadap Kinerja Pegawai Pada Lembaga Penyiaran Publik Televisi Republik Indonesia (LPP TVRI) Kalimantan Timur. Jurnal Administrative Reform, Vol.2 No.4

[16] Rahmatika, Ika. 2014. Pengaruh Kemampuan dan Motivasi Terhadap Kinerja Karyawan Bank BNI Syariah Cabang Bogor. Skripsi. UIN Syarif Hidayatullah.

[17] Patarai, Idris dan Jamaluddin Ahmad. 2015. The Effect of Working Ability And Motivation Performance on Employees The Parks Departemen and Hygiene Makassar In South Sulawesi Province. International Journal of Academic research Vol. 7 No. 4

[18] Verawati. 2015. Pengaruh Kemampuan Terhadap Kinerja Karyawan PT. Nutrifood Indonesia Area Palembang. Skripsi. Universitas Iba Palembang

[6] Isnia, Fariyanti. 2017. Pengaruh Kepuasan Kerja dan Motivasi Kerja Terhadap Kinerja Karyawan PT. PLN (Persero) Distribusi Jawa Tengah dan DIY. Skripsi. Univesitas Katolik Soegijapranata

[19] Yunikewaty. 2017. The Effect of Training and Ability on The Performance of Omployee at Disaster Management Beuruau of Central
Kalimantan Province. Mediterranean Journal of Sosial Sciences MCSER publishing, Rome-Italy. Vol.8 No.3

[20] Astuti, Inna Kusuma. 2018. Pengaruh Kemampuan, Motivasi, dan Lingkungan Kerja Terhadap Kinerja Karyawan di PDAM Tirta Binangun Kulon Progo. Skripsi. Universitas Janabadra Yogyakarta

[21] Bakri, Muhammad. 2018. Effect of Work Ability and Work Motivation on Employee Performance in PT. Lion Mentari Airline in Makassar. Pamjou, Vol.2 Issue 2.

[22] Priyono, Marzuki dan Soesatyo. 2015. Influence Of Motiation and Discipline on The Performance of Employee at CV. Eastern Star Home in Surabaya. Priyono et al.: JGEMBR, 5(3): 212-220

[23 ]Palar, Andika. 2016. The Effect of Work Motivation and Job Satisfaction on Employee Performance at Bank Sulutgo Tomohon.Jurnal Berkala Ilmiah Efisiensi. Vol.16 No.03

[24] Sunarsih. Nenah. 2016. Influnece of Organizational Climate, Motivation, and Job Satosfaction on Employee Peformance. Review of Integrative Bussiness and Economics Research, Vol. 6, Supplementary Issue I.

[25] Dewi, Kartika. 2017. Pengaruh Disiplin Kerja dan Motivasi Kerja Terhadap Kinerja Karyawan PT. Taspen KCU Medan. Skripsi. Universitas Sumatera Utara Medan.

[26] Putro, Nanang Yogi Anggoro. 2017. Pengaruh Motivasi dan Disiplin Kerja Terhadap Kinerja Karyawan Outsourcing PT. ASH Cabang Madiun. Skripsi. UNY

[27] Sibarani, Ernita. 2018. Pengaruh Motivasi dan Disiplin Kerja Terhadap Kinerja Karyawan Pada Rumah Sakit Swasta Lancang Kuning Pekanbaru. Skripsi. Universitas Riau

[28] Dapu, Valensia Angelina Wisti. 2015. "The Influence of Work Discipline, Leadership, And Motivation on Employee Performance at PT.Trakindo Utama Manado". Jurnal EMBA. Vol.3 No.3, Hal.352361

[29] Hidayah, Tamriatin \& Diana Sulianti K.Tobing. 2018. The Infulence of Job Satisfaction, Motivation, And Organizational Commitment To Employee Performance at STIE Mandala Jember. International Journal of Scientific \& Technology Research Vo.7 Issue.7

[30] Sibarani, Ernita. 2018. Pengaruh Motivasi dan Disiplin Kerja Terhadap Kinerja Karyawan Pada Rumah Sakit Swasta Lancang Kuning Pekanbaru. Skripsi. Universitas Riau

[31] Sarwani. 2013. The Effect of Work Discipline and Work Environment on The Performance of Employees at PT. Ardian Putra Mandiri Sidoarjo. Sinergi.Vol.6 No.2

[32] Athins, Nurwati and Sinarwaty. 2018. The Influence of Work Discipline, Organizational Culture, and Work Environmental On Employee Performance at The Kelurahan Employee of Katobu Distric Muna. IOSR-JBM Vol. 20 Issue. 8

[33] Sarwani. 2013. The Effect of Work Discipline and Work Environment on The Performance of Employees at PT. Ardian Putra Mandiri Sidoarjo. Sinergi.Vol.6 No.2

[34] Athins, Nurwati dan Sinarwaty. 2018. The Influence of Work Discipline, Organizational Culture, and Work Environmental On Employee Performance at The Kelurahan Employee of Katobu Distric Muna. IOSR-JBM Vol. 20 Issue. 8

[35] Bakri, Muhammad. 2018. Effect of Work Ability and Work Motivation on Employee Performance in PT. Lion Mentari Airline in Makassar. Pamjou, Vol.2 Issue 2.

[36] Cendaryana, Luddin dan Supriyati. 2018. "Influence of Work Discipline, Career Development and job satisfaction on Employee Directorate General Research and Development of Ministry Research, Technology and Higher Education". International Journal of Scientific Research and Management Vol.06 Issue.02.

[37] Dapu, Valensia Angelina Wisti. 2015. "The Influence of Work Discipline, Leadership, And Motivation on Employee Performance at PT.Trakindo Utama Manado". Jurnal EMBA. Vol.3 No.3, Hal.352361

[38] Cendaryana, Luddin dan Supriyati. 2018. "Influence of Work Discipline, Career Development and job satisfaction on Employee Directorate General Research and Development of Ministry Research, 
Technology and Higher Education". International Journal of Scientific Research and Management Vol.06 Issue.02.

[39] Celluci, Anthony J, and David L. De Vries. (1978). Measuring Managerial Satisfaction: A Manual for the MJSQ, Technical Report II (Center for Creative Leadership). [40] Mas'ud,

[40] Fuad. (2004). Survai Diagnosis Organisasional, Konsep \& Aplikasi. Semarang: Badan Penerbit Universitas Diponegoro.

[41] Barasa L., Gunawan A., Sumali B. 2018. Determinants of Job Satisfaction and it's Implication on Employee Performance of Port Enterprises in DKI Jakarta. International Review of Management and Marketing.ISSN: 2146-4405. 2018. 8(5), 43-49. 